\title{
Albertus Magnus and Rational Astrology
}

\author{
Scott E. Hendrix
}

Department of History, Political Science, and Religious Studies, Carroll University, Waukesha, WI 53186, USA; shendrix@carrollu.edu

Received: 9 July 2020; Accepted: 21 September 2020; Published: 23 September 2020

check for updates

\begin{abstract}
All too commonly scholars take a piecemeal approach toward the work of medieval intellectuals such as Albert the Great (d. 1280), with a view to understanding singly his contributions to the history of science, various philosophical approaches, or theology, as if his mind was somehow compartmentalized. Furthermore, in spite of great advances in studying the history of occult subjects, modern writers sometimes still lapse into writing about medieval astrology as a superstition. This study suggests that we should consider medieval intellectual thought holistically, as a product of a different rationality than that which is dominant today. In order to illustrate this approach, I examine astrological belief within Albert's thought as rational and consider some of the theological reasons why Albert was fascinated with this topic.
\end{abstract}

Keywords: Albertus Magnus; astrology; free will; theology; scholasticism

\section{Introduction}

The historical study of astrology has come a long way since the days of Lynn Thorndike and Dame Frances Yates. Few today look askance at serious scholarly studies of the place of astrology and astrologers in history, as evidenced by the efforts of authors such as Paola Zambelli-whose volume on The Speculum Astronomiae and its Enigma should be the starting point for anyone interested in medieval astrology - and Anthony Grafton-whose highly readable Cardano's Cosmos is destined to become a classic. ${ }^{1}$ Nevertheless there is still much work to be done, since even such fine scholars as Louis Dupré all too often approach premodern astrological beliefs as barriers to the development of modern-and by this term Dupré and others mean rational-modes of thinking. ${ }^{2}$ It is not hard to uncover the rationale for this approach: as the philosophers of science Boris Castel and Sergio Sismundo have said, "The modern world, and perhaps what it means to be modern, is thoroughly entwined with science", 3 and in the modern world the terms "rational" and "scientific" are used as near synonyms. ${ }^{4}$ Therefore, that which is not "scientific" cannot be "rational" and modern scientists such as Carl Sagan and philosophers of science such as Karl Popper are quick to point to the example of astrology as the very epitome of a pseudo-scientific belief. ${ }^{5}$ Whether or not this might be true for the modern world, such a stance leads to confusion when studying premodern Europe, as can be seen in Jean-Pierre Torrell's discussion of medieval "astrological superstitions" in his study of St. Thomas Aquinas: The Person and His Work. ${ }^{6}$ A large part of this confusion arises from a fuzzy definition of what we mean by rational, which I will address below, complicated by an often piecemeal approach

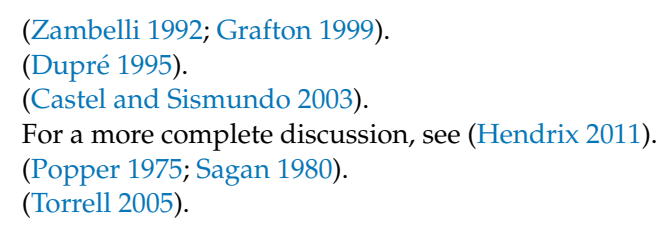


toward the work of medieval intellectuals in which modern scholars approach the work of thinkers such as Albert the Great (d. 1280) with a view to understanding singly their contributions to the history of science, various philosophical approaches, or theology, as if their mind were somehow compartmentalized. This can obfuscate as much as it enlightens. Thus, in the case of Albert the Great, we should move beyond considerations of superstition and consider his astrological beliefs as a rational component of his larger system of thought, with important implications for his theological system.

If we are to understand medieval scholars such as Albert, we must consider theology and natural philosophy jointly within his work. After all, he held a doctorate in theology, and his own starting point when studying the world was the assumption that God created everything in existence, acting as the first cause or the prime mover. Therefore, we should attempt to examine his system of thought from his point of view, as a rational analysis of the world in which he lived. In this analysis, natural philosophy and theology affected one another in important ways. How could that not be the case when all things come from God? And in Albert's view, God is constantly involved with His creation-the cosmos and all that it contains-through the transmission of divine power from his point at the peak of creation down to the terrestrial realm, making a consideration of his astrological beliefs a fruitful entrée into a holistic understanding of Albert's system of thought.

But if we are to understand how astrology, meaning the study of, and a concomitant belief, in the influencing power of the heavenly bodies, was rational for Albert and other medieval intellectuals, we should begin with a consideration of just what we mean by the term "rational". Even a cursory examination of the literature demonstrates that such a seemingly basic and non-contentious term is rather more complex than we might initially assume. The debate about rationality, based as it is on such larger concepts as the nature of evidence and the ontological status of knowledge itself, is wide-ranging, and to attempt a solution here would take me too far beyond the scope of this study, but a few clarifying comments are in order.

A fruitful approach to understanding people of the past is to start with Steven Lukes' view of rationality, whose foundational principle in his analysis of the subject is that "there are contextually-provided criteria for deciding what counts as a 'good reason' for holding a belief", removing "rationality" from the realm of unchanging concepts with independent ontological status. In turn, the work of Peter Winch has influenced Lukes, especially his argument that there is no single rationality, but rather that this concept is only explicable on a contextual basis. Whether or not an individual is rational can only be adjudicated based upon whether or not he or she acts—or thinks-in a way that conforms to the norms of his or her culture. ${ }^{8}$ This is not to suggest that the phenomenological world should be approached from a position of relativism. Rather, the focus of this approach is the way in which objective phenomena are interpreted and understood through the lens of the basic beliefs of the individual. Such beliefs are constructed upon the foundational knowledge and ideas the individual has acquired as part of his or her historical and cultural heritage, which creates a conceptual framework "forced upon [the individual] by his experience of the world". ${ }^{9}$ Therefore, if we want to understand rationality in any given time and place, we must consider the background and cultural norms upon which a particular form of rationality is based.

Most now recognize that this is how people in all times and places function. Within this model of rationality, drawing upon the thought of the sociologist Pierre Bourdieu, rational actors are seen to perform rationality through "a sort of metanoia [meaning a personal change or metamorphosis] marked in particular by a bracketing of beliefs and of ordinary modes of thought and language, which is the correlate of a tacit adherence to the stakes and the rules of the game" ${ }^{10}$ This is precisely what Bruno Latour illustrates when he demonstrated that the adoption of Louis Pasteur's germ theory of disease

\footnotetext{
(Lukes 1967).

(Winch 1964).

(Swinburne 2005).

10 (Bourdieu 1991).
} 
was largely predicated upon ideological or political considerations rather than on the scientific power of the theory. As Latour put it, "laboratories are only one source of science and politics among many sources" ${ }^{11}$ For Latour, science is a pursuit in which scientists do their work according to the rules of a game drawn from societal and cultural expectations, much like Thomas Kuhn's view of normal science as a system of puzzle-solving in which the rules are so firmly set that those working within a particular paradigm cannot even communicate with those working within a different paradigm. ${ }^{12}$

In the high Middle Ages, the rules of this game were set through the exercise of institutional capital orchestrated within the locus of the various universities that had been established across Europe, beginning with the University of Bologna in $1189 .{ }^{13}$ Within this context, intellectuals dealing with natural philosophical questions were most often university graduates, who assumed that an investigation of the natural world through the application of rules established by Greek and Hellenistic thinkers such as Aristotle (d.322 BCE) and Ptolemy (fl. 150) represented what it was to be a rational individual. ${ }^{14}$ The result was a premodern European intellectual class who shared a set of presuppositions taken for granted and held to be beyond dispute-a habitus, in Bourdieu's terminology -inculcated through their common education. ${ }^{15}$ The component parts of this education most relevant to our current study included the reading of a shared literature written primarily by Greek and Arabic authors, understood through shared forms of analyses driven by basic assumptions about the world, derived from this common experience and reinforced by the authority of professors, degree-granting institutions, and the professionalization of the intellectual class in Europe.

Far from some medieval aberration, this model of rationality is normative; the questions one asks and the basic contexts within which one interprets data or evaluates ideas ordinarily derive from the culture within which one lives. ${ }^{16}$ Therefore, in the absence of revolutionary paradigmatic belief changes, a society typically develops in the context of older ideas, as individuals analyze the world around them through the lens of their education, experiences, religion, and other important aspects of their worldview. Very few, if any, beliefs can be considered freestanding; instead, concepts, interpretations, and analyses are conjoined to those a person has acquired through his or her cultural and intellectual heritage. ${ }^{17}$ It is the conjunctive nature of beliefs that make astrology in premodern Europe thoroughly rational, built as it was on an internally consistent set of principles validated both by empirical evidence interpreted through the lens of the astrological conceptual model and methods of analysis constructed over many centuries that had survived repeated challenges and testing. The history of the development of astrological systems of thought, from the fifth-century Babylonians who first cast horoscopes intended to describe an individual's future ${ }^{18}$ to the elaboration of Greek thinkers such as Plato (d. 347 BCE) and Aristotle, as well as Hellenistic successors such as Ptolemy (fl. 150) -not to mention those of the Near East, such as Abū Ma'shar al-Balkhī (d. 886), which jointly created the system eventually bequeathed to Medieval Europe through the translation efforts of scholars such as Adelard of Bath (c.1152) - is too complex and wide-ranging to tell here. ${ }^{19}$ What is important to recognize is that by the high Middle Ages European scholars accepted a cosmology developed and

11 (Latour 1988). Beginning on 176, Latour even goes so far as to attack the principles of logic, stating: “There has never been such a thing as deduction... Those who talk of synthetic a-priori judgments deride the faithful who bathe at Lourdes. However, it is no less bizarre to claim that a conclusion lies in its premises than to believe that there is holiness in the water".

12 (Kuhn 1970).

13 (Grant 1996).

14 Cf. Bourdieu's analysis of the functioning of investigators within the modern scientific fields. (Bourdieu 1991, p. 8).

15 This included an understanding of rationality drawn from Aristotle, according to which human function is a rational activity. Human good is a function of rational activity performed well, which Aristotle takes to mean in accordance with virtue. Thus, for Aristotle, behaving rationally meant behaving in accord with virtue. This is important to Albert's view of human action and his definition of rationality. However, what we are considering here is how rationality is defined and constructed, rather than the scholastic definition of rationality. See (Korsgaard 2008; Gallagher 1991).

16 (Longino 1990).

17 (Swinburne 2005, pp. 4-9).

18 (Sachs 1952).

19 For a useful introduction to the history of astrology, see (Tester 1987). 
articulated over many centuries, built on widely accepted empirical standards, including the idea of celestial influence passing downward through the spheres to the Earth as a central component. As Ptolemy stated in his second-century work, the Tetrabiblos, which served as a foundational work on astronomy and astrology down to the fifteenth century and beyond,

A very few considerations would make it apparent to all that a certain power emanating from the eternal ethereal substance is dispersed through and permeates the whole region about the earth, which throughout is subject to change, since, of the primary sublunar elements, fire and air are encompassed and changed by the motions in the ether, and in turn encompass and change all else, earth and water and the plants and animals therein. ${ }^{20}$

\section{Astrology and Medieval Rationality}

For thinkers working within a monotheistic setting, there was a problem with the classical cosmological model bequeathed to them, which included a large role for astrological influence: Ptolemy was working within a very different system of rationality than that of Christian intellectuals of the Middle Ages, one that did not privilege free will or divine power. After all, Ptolemy was working from a broadly Aristotelian set of assumptions, in which the universe was eternal.

Fortunately for theologians such as Albert, intellectuals working within an Islamic context elaborated and developed this system into one that presupposed Ptolemy's "certain power" to be God's divine influence. ${ }^{21}$ The Muslim astrologer whose works most influenced the West addressed this charge and provided the justification that Albert would promote in his own defense of astrology was Abu Ma' shar Ja'far bin Muhammad al-Balkhi, known to the West as Albumasar (787-886). ${ }^{22}$ Albumasar saw astrology as so important that he argued the discipline was superior to all other forms of natural philosophy. Most importantly, he believed it provided the basis for the other sciences, while fields such as medicine merely expanded its principles in a narrowly utilitarian fashion. ${ }^{23}$ To promote astrology, Albumasar wrote compendiums of astrological axioms intended as practical manuals. ${ }^{24}$ For Albumasar, all thought was derived from a single antediluvian revelation, leading him to believe a scholar could arrive at a single "Truth" by piecing together elements from different sources. ${ }^{25}$ Ultimately, his methodology led him to an important original contribution, allowing for a reconciliation between astrology and Islamic religious principles. Albumasar introduced the concept of the "rational soul", or a person's free will coupled with the cognitive abilities that differentiated him from animals, which was free from the influence of the stars. ${ }^{26}$ This soul, along with all else that a person possessed, came from God. ${ }^{27}$ This element of the soul led Albumasar to argue that "the wise man will dominate the stars", in his Introductorium maius. ${ }^{28}$ What he meant by this is that one knowledgeable in celestial influences is able to counteract those forces, freely choosing to act in

20 (Ptolemy 1940).

21 The most thorough study of this process is still Lemay's Abu Ma'shar and Latin Aristotelianism in the Twelfth Century (Lemay 1962).

22 (Pingree 1990; Hendrix 2006).

23 (Lemay 1962, p. 242).

24 (Pingree 1968).

25 Ibid., pp. 18, 33. John D. North has pointed out that Abu Ma' shar's astrology was itself an "amalgam of Hellenistic and Indian astrology". See (North 1986).

26 (Lemay 1962, p. 84). For Abu Ma' shar, this was different from the passive potency Plato referred to in the Republic, which is often translated as the "rational soul". For Plato, this soul was separate from the will, which acts at the behest of the rational soul. Abu Ma' shar's concept is closer to the way in which medieval scholars, such as Albertus, viewed Aristotle's intellectual or intelligible soul, though will and intellect are closely combined in Abu Ma' shar, whereas Albert sees will as a component of the intellectual soul. See (Plato 1991; Bremmer 1987; Albertus 1993).

27 (Lemay 1962, pp. 82-83), quoting from Abu Ma' shar's Introductorium maius: "The third cause of his being, the virtue of heavenly bodies by the will of God produces in him whatever else he has ... [including] the differentiation of his species from all others and his individuality ... [as well as] the establishment of a suitable harmony between his vital and rational soul on one hand and his body on the other". The translation is Lemay's.

28 (Lemay 1962, pp. 42-48). 
accord with one's will instead of the influences that otherwise impel one toward actions in accord with physical desires.

This maxim, commonly presented in Latin as "sapiens dominabitur astris", became a commonplace among Western Christian intellectuals-with none cherishing this concept more than Albert, who cited it repeatedly throughout his corpus of works-as a shorthand for the idea that though the heavens might exert a strong influence on humans, free will was still intact. ${ }^{29}$ Thus humans sat at the center of a web of influence that was part of a cosmological model in which all things are interconnected, with the human body presumed to be a microcosmic representation of the larger macrocosm of the universe. Celestial motion, combined with the qualities of individual celestial objects, affected the four humors of the human body through emitted rays. Nevertheless, that part of what makes us human, our intellectual soul and our free will, allows humans to resist these influences through the exertion of enough effort, for they affect the soul only secondarily, through effects on the body. From our twenty-first-century perspective, all of this might seem decidedly odd, but we should keep in mind why and in what ways this was a rational model for understanding the world: astrology represented a model of the universe in which physical bodies interacted with one another with perfect, mathematically describable consistency, requiring no belief in invisible entities or divine intervention to explain everything from the movements of the planets to the coming to be and passing away of terrestrial objects.

Understanding this point is important, for it represents a perfect example of the way in which basic beliefs functioning conjunctively with those logically developed or derived from them can lead to a thoroughly rational system operating within different parameters than those established by modern science. ${ }^{30}$ In short, beginning from the presumption that Aristotelian physics is the best possible model for understanding change and causality in the world, placed within the Neoplatonically influenced monotheistic cosmological model developed by Albumasar and other Arabic-language scholars who established God as the Prime Mover transmitting his impelling force through the cosmos via the agency of light, the concept of celestial influence makes perfect rational sense. Working from this basic set of assumptions, belief in the predictive and analytical power of astrology becomes an almost necessary entailment. For the individual who accepts the premise that celestial patterns determine or influence events in the terrestrial realm, astrological analysis of past or present events or phenomena and the prediction of future events through scrutiny of the influence that the heavens transmit as they move in their perfectly ordered fashion becomes simply a matter of mathematical astronomy. Furthermore, seeing humanity as fitting into this interconnected system, beginning with God and flowing downward to each individual person, demonstrates why for medieval intellectuals such as Albert, this natural philosophical understanding of astrology had important theological implications and was thus worthy of study.

True, astrology was not accepted without dissent; in fact, there were those in the medieval West who viewed astrology with considerable distaste. One of the best examples is Stephen Tempier (d. 1279), the bishop of Paris, who first in 1270 and then again in 1277 headed a commission that issued condemnations of a range of Aristotelian positions. While not primarily directed at astrology, these condemnations did represent a thoroughgoing assault on the discipline. Rejecting the notion that celestial influences dispose people to differing personalities and gifts, that anyone's health or sickness is dependent upon the locations of heavenly bodies, or even that the stars might indirectly affect an individual's soul, it is clear that Tempier would brook no sympathy toward astrological beliefs. ${ }^{31}$

29 Medieval intellectuals commonly, though mistakenly, cited Ptolemy as the source of this concept. G. W. Coopland attempts to trace the provenance of this maxim in appendix four of his work, Nicole Oresme and the Astrologers: A Study of his Livre de Divinacions (Coopland 1952). One should note that Coopland does not give any indication that it had entered the vocabulary of Latin Christian writers prior to Albert's use of the saying. It seems likely that Albert was the one who passed this phrase on to those he influenced. Paola Zambelli notes that Albert "cherished" the dictum, quoting it repeatedly. See (Zambelli 1982).

30 Richard Swinburne addresses both "basic beliefs" and the "conjunctive nature of ideas", pp. 3-24.

31 (Wippel 1977; Denifle and Chatelain 1889). 
Whatever the other effects of the Condemnations of Paris of 1277, the death of astrology was not one of them. ${ }^{32}$ If anything, the opposite was the case. As the number of university graduates multiplied in medieval Europe-all of whom would have had some familiarity with Aristotelian physics as well as the basics of astronomy and its sister discipline astrology-there was a concomitant increase in the number of people with both the knowledge base and an interest in promoting the study of astrology. Furthermore, of the roughly 750,000 students who entered European universities between 1350 and 1500 , all who progressed to a study of the quadrivium would have garnered some knowledge of the celestial disciplines, as they read not only Aristotle and Ptolemy, but also John of Sacrobosco's Tract about the Sphere, Gerard of Cremona's Theory of the Planets, and Albumasar's Introductorium maius. ${ }^{33}$ Thus, university education created a premodern habitus that included a belief in the active power of celestial forces on the sublunary realm. We can see the strength of this habitus when we consider that in spite of periodic challenges about its efficacy or permissibility to Christians by intellectuals such as the fifteenth-century Chancellor of the University of Paris, Jean Gerson (d. 1429), few or none rejected the idea that the heavens influenced all terrestrial objects, including human bodies. Within this system of thought, it was wholly rational for Albert the Great to give serious thought to astrological implications within his theological system.

\section{Albert on Astrology and Free Will}

Although many medieval intellectuals wrote about astrology, Albert was interested in this discipline to an unusual degree, seeing an understanding of it as having great importance within his theological system. The importance he placed upon astrology is demonstrated by the frequent references Albert makes to celestial influence, ranging from discussions of the usefulness of various forms of divination to simple mentions of astrological principles as support for other arguments. Such citations are present in everything he wrote, from his earliest work, De natura boni, to his last, the unfinished Summa theologiae. ${ }^{34}$ In order to understand why Albert made such frequent allusions to celestial influences and astrology, we should consider his position regarding the relationship between free will and the essential nature of that which is human, starting with his early commentary Super ethica, written between 1250 and $1252 .{ }^{35}$ The crux of his discussion as it relates to our current subject is the distinction made between voluntas and desiderium. The former is that peculiarly human trait, free will, which is a faculty of the intellectual soul. But the latter is a hollow and meaningless longing, distorting our understanding of the good by tempting the appetites. ${ }^{36}$ This longing causes us to mistake those things that can lead to voluptas, or sensual pleasure-which, as an end, is fit only for beasts-for those things that bring felicitas, or true happiness. ${ }^{37}$ An object desired due to a sensible longing is the product of the sensible soul, rather than chosen through an act of the will. Therefore, such objects can never represent an end worthy of a human ${ }^{38}$ standing, untouched as they are by reason; for, according to Albert, and in line with Aristotle, "the work of man, insomuch as he is a man, is a work of reason", and works performed through the application of reason are, by definition

32 Some grand claims have been made about the importance of the Condemnations of Paris of 1277. Pierre Duhem sees them as the beginning of modern science. Other scholars, such as L. Bianchi, have attributed a far more limited impact to the Condemnations. See (Duhem 1913-1959).

33 Edward Grant calculates the number of students who attended European universities between 1350 and 1500 , in his work The Foundations of Modern Science, (Cobban 1999, pp. 37-38, 44-45; Tester 1987, pp. 192-93).

34 (Thorndike 1923).

35 (Albertus 1968a, pars I, p. vi).

36 Ibid., pars I, pp. 7, 10. "vacuum est desiderium", which "Omne quod appetit, appetit per modum artis vel naturae; sed torquere [desiderium] appetit bonum". All translations from Latin are my own.

37 Ibid., pars I, pp. 17, 21 "Voluptas nulla lege ordinatur", and "non videtur pertinere ad bonam vitam", because "voluptas est bonum bestiarum".

38 Ibid., pars I, p. 10. 
good—and human—acts. ${ }^{39}$ True, some actions such as feeding the poor are inherently good, ${ }^{40}$ but for a person to participate fully in the goodness of the action he or she must choose to undertake the act through application of the will. ${ }^{41}$ Ultimately, even though "reason is never deflected from uprightness" under optimal circumstances, such a deflection can indeed come about when the individual is moved "by another inclination, such as from concupiscence or wrath, which corrupts prudent assessment", ${ }^{4}$ and in such circumstances the individual behaves as a beast. Sin, then, is the result of a failure to engage the rational soul, which is what occurs when one acts in accord with the sensible—-that is, animal—soul.

In Albert's system, a broad range of influences drive us to behave in an animalistic fashion, but none is greater than that derived quite literally from the highest source possible, that is, "the rays of diverse stars" 43 affecting the body and influencing the soul per accidens toward actions, as the body tugs upon the soul. As Albert explains in his commentary De caelo, God acts first on the highest level within the hierarchy of the created universe, the orb of the celestial bodies, influencing everything beneath it ${ }^{44}$ through a downward emanation of power passing through the various levels of the hierarchy of creation. ${ }^{45}$ As God's power flows downward from his being and through the lower levels of reality, this flow alters its impact, making the motive process the primary affective force, as opposed to the substance of the influencing "ray" itself. ${ }^{46}$ In this model, influence emanating from the heavens explains a wide variety of observable Earthly phenomena, ranging from the actions of individual elements, including the process of generation and corruption, to the passage of time itself. ${ }^{47}$ Perhaps most significantly, celestial light becomes diffused as an actuating force upon terrestrial beings, 48 "illuminating" the souls of humankind and affecting them per accidens through their impact upon the human body. ${ }^{49}$ Should he so choose, God could directly interact with the universe, intervening in a miraculous fashion, but in Albert's view, he prefers to work his will through the celestial intermediaries created precisely for this purpose..$^{50}$ In this way, Albert utilizes a Neoplatonic emanatory aspect of light, modified as an actively willed instrument, in a Christianized Aristotelian system. ${ }^{51}$

39 Ibid. pars I, p. 40. “Opus hominis, inquantum homo est, est rationis ... oportet, quod opus hominis inquantum homo sit idem quod opus boni".

40 (Cunningham 2008).

41 Cunningham takes note of Albert's insistence in the De bono on the importance of choosing to act in accord with reason, but he fails to follow Albert's argument through to its logical conclusion. See (Cunningham 2008, pp. 135-38).

42 Albertus, Super ethica, pars I, p. 40. "Ratio numquam deflectitur a rectitudine, nisi alio quodam inclinante, scilicet concupiscentia et ira, quae corrumpit aestimationem prudentiae".

43 Ibid. pars I, p. 81. "quod inducunt de radiis diversarum stellarum".

44 (Albertus 1971): pars I, p. 4. "Magnificamus deum creatorem, qui eminet proprietatibus omnium creaturarum ... eo quod eius actus manifestatur in naturalibus". Pars I, 23. "Deus non continetur caelo, sed potius est in ipso sicut motor indivisibilis ... Rationabiliter autem iudicaverunt omnes gentes deum esse in caelo. Deo enim dederunt potestatem causandi et creandi ista inferior, et ideo, cum ab uno non possit esse nisi unum et ab uno ... quod non incepit, non possit esse diversitas aliqua secundum naturam, dederunt ei caelum, quod in substantia ingenerabile est et secundum motum diversificatum, ut movendo illud causet nova inferior diversa eo modo. . . ut per motum locale corporis huius [Deus] causet mutationem omnem in inferioribus et diminutionem et additionem et corruptionem et remotionem et alterationem".

45 For a detailed explication of the emanatory process in Albert's works, compared to emanation as Plotinus and his intellectual descendants presented it, see Thérèse Bonin's Creation as Emanation (Bonin 2001).

46 (De Libera 1990). This is what the author refers to as Albert's "metaphysic of flows", to emphasize the important role of the "flowing" of divine influence from point to point in creation, rather than the simple power of the light involved.

47 Albertus, De caelo, pars. I, 56. The most concise description of Albert's ten-sphere system of the universe is found in his Problemata determinata, Jacob Weiseipl, ed. (Albertus 1975b). "His [the nine upper spheres] coniungunt ad sphaeram activorum et passivorum, et est orbis quattuor essentiarum simplicium, quae dicuntur esse elementa".

48 (Albertus 1955).

49 Albertus, De caelo, pars I, p. 57. "super animas hominum illustrat".

50 If we are willing to accept the Speculum astronomiae as a genuinely Albertine work, this is where we find the clearest statement of the view that God works his will upon the earth through the stars, as if they were his instruments. See Albertus Magnus, Speculum astronomiae, as included in Paola Zambelli's The Speculum Astronomiae and its Enigma: Astrology, Theology, and Science in Albertus Magnus and his Contemporaries (Zambelli 1992): "Ipse qui est Deus vivus, Deus caeli non vivi, velit operari in rebus creatis ... per stellas surdas mutas sicut per instrumenta". On the authorship of this work, see (Hendrix 2010).

51 This model, with its Neoplatonic elements, is representative of Albert's system of thought as a whole. He derived the idea that God's influence flows as a stream of light through each of ten heavens downward to the terrestrial realm from De causis et processu universitatis a prima causis. Albert's system of thought appears broadly Aristotelian, yet instances such as this one 
Albert provides one of his most thorough discussions of the complex influences the heavens can ultimately impart to the terrestrial realm in his work De fato. ${ }^{52}$ Here he discusses some of the possible influences of the heavenly bodies on conception, infant mortality, and the characteristics a developing infant can acquire through celestial interaction with terrestrial elements. ${ }^{53}$ Each of the planets has a different dominant nature; for example, Saturn has a "cold and dry" nature. ${ }^{54}$ These natures function as contingent variables acting upon the development of bodily organs and humors. ${ }^{55}$ In this way, the flow of influence that begins with God arcs downward to eventually affect the development of all terrestrial creatures, including human beings, in a manner that largely determines both an individual's health and personality. ${ }^{56}$ Albert's belief in the indirect, but powerful, influences of celestial bodies upon a person's inner being explains why he maintained that one wishing to understand the functions of the soul should begin by studying the interactions and influences of celestial bodies. All things are from God-the Christian equivalent of the Prime Mover-but by "influencing [man] through the motion of heaven [he] regulates and causes the intellectual operations of the soul" and impresses change secondarily "on the rational soul". .7

As these celestial forces affect the human body they result in a strong influence toward a certain behavior or action. Certainly, such motivations are mere influences and one may resist them, but only through an intentional act of will. ${ }^{58}$ Furthermore, resisting celestial influences requires great effort, due to the nature of heavenly bodies as necessary causes, being absolutely regular in their motions and composed of perfect quintessence. Thus, any such influence "is more firm within us than that which is from a cause that is not necessary". ${ }^{59}$ The motivations imparted to our sensible appetites by these heavenly forces drive us toward harmful action, ${ }^{60}$ causing us to act in a sinful and bestial manner.

Of course, for Albert, people are free agents, possessing the highest form of soul present in the terrestrial realm, an intellectual soul complete with its capacity for free will. In fact, Albert maintained that one would never knowingly act in accord with negative impulses, ${ }^{61}$ but in his view the actions

remind us that his philosophical system contains a larger Neoplatonic element than might be immediately evident to a casual reader. For an exploration of some important examples of Neoplatonism in Albert's thought, see Bonin, pp. 1-3, passim.

53 Ibid., p. 66.

54 Ibid., p. 66.

55 (Grant 1994). Grant discusses the different properties and natures of the planets. These varying characteristics did present an apparent conflict. The planets were held to be composed of a perfect substance (quintessence) and thus could not have accidental properties. Therefore, it seems as if they should have had perfectly uniform influences, rather than differing from one planet to the next. Medieval scholars held the differentiation in influence to be explainable partly through the orbital positions of these planets. Some scholars argued that all earthly effects, such as heat or cold, came from celestial influences, but that these effects only existed as manifested in the patient. By the fourteenth century, the characteristics that were seen to incline a terrestrial patient toward a certain result, such as being hot-tempered or sickly, existed virtually (virtualiter) in the celestial region, but not formally (formaliter).

56 Albertus, "De fato", pp. 68-71. It is abundantly clear that Albert also accepted the idea that one knowledgeable about the influences imparted by the heavens could also predict the likely future of an individual, as Zambelli outlines on pages 65-67. For example, see what Albert has to say in his commentary De generatione et corruption (as quoted by Zambelli): "et hoc modo innotescit, quoniam qui sciret vires signorum et stellarum in ipsis positarum in circulo periodali dum nascitur res aliqua, ipse quantum est de influentia caelesti praenosticari posset de tota vita rei generatae".

57 Albertus, "De fato", p. 66. "[Intelligentia] influens per motum caeli regulat et causat operationes intellectuales animae". "sic est in omnibus moventibus et motis quae distant invicem. similiter est intelligentia et anima: quoniam intelligentia distat, et imprimit in animam rationalem secundum locum distans ab eo". In this quote Albert is relating Aristotle's view of the influence of the way the Prime Mover influences sublunar events, at least as Albert understood the Philosopher's position. From a Christian perspective, the "intelligence" in question, the Prime Mover, is God. There is no doubt that Albert accepts the view that God's influence orders the cosmos through celestial bodies, as indicated in the solutio on p. 68 : "dicitur fatum forma ordinis esset et vitae inferiorum, causata in ipsis ex periodo caelestis circulis ambit nativitates eorum ... Forma autem ista causata ex caelesti circulo et inhaerens generabilibus et corruptibilibus".

58 Albertus, Super ethica, pars I, p. 84. Albert makes a vivid argument by analogy between those things that influence the soul through the body and the persuasive force a father can exert over his son, or a friend over a friend. "Id est persuasivum ad opus, sicut pater persuadet filio et amicus amico".

59 Ibid. pars I, p. 66. "Illud quod est per causam necessariam, firmius est in nobis quam quod per causam non necessariam". For a more detailed discussion, see Albert's commentary, De physica, Paul Hossfeld, ed. (Albert 1987, pars I, pp. 116-18).

60 Ibid., pars I, p. 84. "quod est pars sensitivi appetitus, quo propulsatur nocivum".

61 Ibid., pars I, pp. 145-46. "Dicendum, quod omnis malus est quodammodo ignorans et habet ignorantiam electionis". Albert certainly had it on good authority that free will can only be directed toward a good end, unless twisted by an outside 
human beings take do not always involve the intellect. Instead, people regularly and unknowingly allow themselves to act in accord with the influences affecting them. ${ }^{62}$ Humans, as composite beings made up of souls enmeshed within imperfect matter, are all too easily moved by the corporeal influences imparted by celestial influences, since "there is a two-fold principle of actions in man, that being nature and free will". ${ }^{63}$ Our will is indeed free, but our natural self, that part of us made up of our generated, corporeal being, is ruled by the stars. ${ }^{64}$ Therefore, unless our will "struggles, it is drawn and hardened by our natural self, and when the natural self is moved by the motions of the stars, the will then begins to incline toward the motions of the stars and the constellations" ${ }^{65}$

Now we are getting close to why Albert considered astrology so important, and why for him this was not simply a natural philosophical question, but instead one with important implications for theology. Within Albert's system of thought, it is very useful, if not absolutely vital, to understand fate if one is to function in accord with God's will, but for him "fate" does not negate free will. Instead, for Albert fate is the pattern of influence existing in its pure form in the celestial spheres. Therefore, it is a "necessary cause", meaning that the combination of perfectly incorruptible material with perfect motion in the celestial realms provides necessarily predictable influences. Thus, a motion or an effect has an unchanging and invariable nature. ${ }^{66}$ However, this perfection of order cannot be received "in generated things. Because of the mutability of their being, it is received mutably and contingently". ${ }^{67}$ Celestial bodies do have a necessary nature and

therefore it should be said, that the cause of fate is necessary; but from this nothing else follows except that being itself is necessary, but it does not follow that it imposes necessity upon things: because [necessity] does not inhere in things according to the power of the heavens, which [i.e., the heavens] are necessary, but according to the power of inferior things, which are completely contingent and mutable. ${ }^{68}$

Thus, by the time celestial bodies communicate their influence to the terrestrial realm, the result is not something that must happen, but merely something likely to happen. ${ }^{69}$ For Albert, this understanding of causality is perfectly logical; otherwise, inferior sub-lunar creatures would behave as predictably as those in the supra-lunar realm. The motions of the celestial bodies are uniform and predictable, setting up the preconditions that would allow for successful astrological predictions. Although such predictions could only provide information about probable events, Albert felt that such knowledge- built as it was on knowledge of influences-could be quite beneficial, because of its ability to perfect the actions of the intelligible soul, unique to humans in the sublunar sphere. This aspect of the soul provides the ability to reason and contains the rational appetite, enabling a human to incline him or herself toward an object through a cognitive choice, an ability synonymous with the will. ${ }^{70}$ But since the sensible soul common to humans and animals imparts a sensory input capable of generating corporeal desires ranging from lust to rage, these "fancies" or "desires" regularly motivate people to act without

influence. In his commentary on Matthew, Albert adduces Aristotle and John Damascene in agreeing with Augustine, whom he quotes as saying "Voluntas namque non est nisi in bonis; in malis flagitiosisque factis non voluntas, sed cupiditas proprie dicitur". (Albertus 1987a, 1987b).

62 Paola Zambelli has also noted the importance of Albert's Super ethica to understanding his view of the relationship between free will and celestial influence. See Zambelli, p. 176.

63 (Albertus 1890). "Est enim in homine duplex principium operum, natura scilicet et voluntas".

64 Ibid, I.II, p. 51. "Natura quidem regitur sideribus, voluntas quidam libera est".

65 Ibid., I.II., p. 51. "sed nisi renitatur, trahitur a natura et induratur, et cum natura moveatur motibus siderum, incipit voluntas tunc ad motus siderum et figuras inclinare".

66 Albertus, "De fato", p. 68.

67 Ibid. "in rebus autem generatis, propter mutabilitatem ipsarum esse, est recepta mutabiliter et contingenter".

68 Ibid. "ergo dicendum, quod fati causa necessaria est; sed ex hoc non sequitur aliud nisi quod sit necessarium ipsum esse, sed non sequitur quod necessitatem rebus imponit: quia non inhaeret eis secundum potestatem caelestium, quae necessaria sunt, sed secundum potestatem inferiorum, quae omnino mutabilia et contingentia sunt".

69 Ibid., p. 49. Necessary modes of causality cannot exist within the sub-lunar realm. Thus, all terrestrial effects are the result of causalities representing varying levels of likelihood that effects will come to pass.

70 (Albertus 1968b). 
exercising the will, ${ }^{71}$ making it possible-perhaps even normative- - to act according to an impulse of the sensitive appetite. ${ }^{72}$ So how can knowledge of celestial influence and events that will probably occur be useful? Simple: the will may function more freely and in greater accord with God's precepts through the exercise of celestial divination, allowing one to understand outside influences better, correcting them as needed. ${ }^{73}$ We should always be mindful, though, that according to Albert only when a person acts in a purely logical fashion can he or she be free of outside influence, including that exerted by celestial bodies. Therefore, since people are normally carried along by their impulses, astrologers can make "conjectures" based on celestial observations with a high degree of accuracy in most cases. ${ }^{74}$ In this way, knowledge that allows us to understand those celestial influences driving our behavior enables us to live more in accord with God's will and the standards of behavior dictated by our essential nature as beings possessing an intellectual soul and the free will that goes along with it.

In summation, Albert sees the study of the heavens and celestial influence as essential for understanding God's plan for humankind, because for Albert astrology is a "great wisdom" providing "a link between natural philosophy and metaphysics". ${ }^{75}$ This is important for

if God ... has ordered this world ... as to operate in created things ... through stars ... as if through instruments ... what could be more desirable to the thinking man than to have a middle scientia [between natural philosophy and metaphysics] that may teach us how this and that change in the mundane world is effected by the changes in the heavenly bodies. ${ }^{76}$

Knowledge of what God would have us do rests in the intellectual soul, but is difficult to discern due to the insidious celestial accretions acquired on the long descent through the celestial spheres to the terrestrial realm. Through the study of astrology, one can learn to distinguish human desires emerging from the intellectual soul from those that derive from heavenly bodies. It is in this way that people not only can act in accord with God's divine plan, but also understand that plan through analysis of the multiple ways in which corporeal elements act on one another. Thus, Albert's position, constructed rationally and developed in great depth, maintained that celestial forces play an important role and act as transmitters of divine influence.

Funding: This research received no external funding.

Acknowledgments: There are many people I should thank for supporting my work. Richad Lemay was very generous with his time, before he passed away. Laura Ackerman Smoller has been a continuous source of support, information, and inspiration. I wouldn't be where I am without Thomas Burman. I also very much appreciate Kiki Zhang's invitation to write a paper for the Special Issues project.

Conflicts of Interest: The author declares no conflict of interest.

71 Ibid., p. 241; Albertus, Questiones, pp. 219-20. Desires “non sint per essentiam de natura rationis, participant tamen cum ratione".

72 In scholastic terminology the sensitive appetite is the force that provokes an agent to action through the corporeal senses. Properly speaking, the will is associated only with the intellectual appetite.

73 Albertus, "De fato", pp. 68-69.

74 Albertus, Questiones, p. 59. "astronomi non dant principia, ex quibus contingit prognosticari aliquid de his quae subsunt libero arbitrio, secundum quod subsunt illi, sed coniecturantur de dispositionibus corporum, quae inclinare et retrahere liberum arbitrium, sicut corpus trahit animam".

75 Albertus, Speculum, pp. 218-221. "Secunda magna sapientia, quae similiter astronomia dicitur, est scientia iudicorum astrorum, quae est ligamentum naturalis philosophiae et metaphysicae". This, of course, assuming the Speculum is a genuinely Albertine work. But even if not, this mirrors the sentiment expressed in a great many of Albert's undoubtedly genuine works.

76 Ibid., p. 220. "si ... ordanavit Deus ... mundum istum ... velut operari in rebus creatis ... per stellas ... sicut per instrumenta ... quid desideratius concionatori quam habere mediam scientiam, quae doceat nos qualiter mundanorum ad hoc et ad illud mutatio caelestium fiat corporum mutatione". 


\section{References}

\section{Primary Sources}

Albertus Magnus. 1890. De Mineralibus. Edited by Auguste Borgnet. Paris: Vives, vol. II.

Albertus Magnus. 1955. Liber de Natura et Origine Animae. Edited by Bernhard Geyer. Aschendorf: Monasterii Westfalorum.

Albertus Magnus. 1968. De anima, pars I, Opera omnia. Edited by C. Stroik. Monasterii Westfalorum: Aschendorff. Albertus Magnus. 1968. Super ethica: Commentum et Queastiones. Edited by Wilhelm Kubel. Aschendorf: Monasterii Westfalorum.

Albertus Magnus. 1971. De caelo et Mundo. Edited by Paul Hossfeld. Aschendorf: Monasterii Westfalorum.

Albertus Magnus. 1975. De fato. In Opera Omnia. Edited by Paul Simon, Aschendorf: Monasterii Westfalorum, vol. 17.

Albertus Magnus. 1975. Problemata Determinate. Edited by Jacob Weiseipl. Aschendorf: Monasterii Westfalorum. Albertus Magnus. 1978. SummaTheologiae sive De Mirabili Scientia Dei, Libri I, Pars I, Quaestiones 1-50A. Edited by Dionyisius Siedler, P. A. Wilhelm Kubel and Heinrich George Vogels. Aschendorff: Monasterii Westfalorum.

Albertus Magnus. 1987a. Super Matthaeum. Edited by Bernhard Schmidt. Aschendorf: Monasterii Westfalorum.

Albertus Magnus. 1987b. De physica. Edited by Paul Hossfeld. Aschendorf: Monasterii Westfalorum.

Albertus Magnus. 1993. Questiones. Edited by Albert Fries. Aschendorf: Monasterii Westfalorum.

Denifle, Henri, and Emile Chatelain, eds. 1889. Chartularium Universitatis Parisiensis. Paris: Delalain, vol. I.

Plato. 1991. Republic. Translated by Benjamin Jowett. London: Vintage.

Ptolemy. 1940. Tetrabiblos, Loeb Classical Library Edition. Edited and translated by F. E. Robbins. Cambridge: Harvard University Press.

\section{Secondary Sources}

Bonin, Thérèse. 2001. Creation as Emanation. Notre Dame: Notre Dame University Press, pp. 45-48.

Bourdieu, Pierre. 1991. The Peculiar History of Scientific Reason. Sociological Forum 6: 3-26, 8. [CrossRef]

Bremmer, Jan N. 1987. The Early Greek Concept of the Soul. Princeton: Princeton University Press.

Castel, Boris, and Sergio Sismundo. 2003. The Art of Science. Toronto: UTP Higher Education, p. 9.

Cobban, Alan. 1999. English University Life in the Middle Ages. Columbus: Ohio State University Press, pp. 158-60.

Coopland, George William. 1952. Nicole Oresme and the Astrologers: A Study of his Livre de Divinacions. Cambridge: Harvard University Press, pp. 175-77.

Cunningham, Stanley B. 2008. Reclaiming Moral Agency: The Moral Philosophy of Albert the Great. Washington: Catholic University of America Press, pp. 116-17.

De Libera, Alain. 1990. Albert le Grand et la Philosophie. Paris: J. Vrin, pp. 116-18.

Duhem, Pierre. 1913-1959. Le Système du Monde. Histoire des Doctrines cosmologiques de Platon à Copernic. Paris: Hermann, vol. VIII, p. 7; vol. IX, p. 374; vol. X, p. 27.

Dupré, Louis. 1995. Passage to Modernity: An Essay in the Hermeneutics of Nature and Culture. New Haven: Yale University Press, pp. 56-57.

Gallagher, David M. 1991. Thomas Aquinas on the Will as Rational Appetite. Journal of the History of Philosophy 29: 559-84. [CrossRef]

Grafton, Anthony. 1999. Cardano's Cosmos: The Worlds and Works of a Renaissance Astrologer. Cambridge: Harvard University Press.

Grant, Edward. 1994. Planets, Stars, and Orbs. Cambridge: Cambridge University Press, pp. 204, 227, 467-69.

Grant, Edward. 1996. The Foundations of the Modern Sciences in the Middle Ages. Cambridge: Cambridge University Press, chp. 3.

Hendrix, Scott E. 2006. Reading the Future and Freeing the Will: Astrology of the Arabic World and Albertus Magnus. Hortulus 1: 30-49.

Hendrix, Scott E. 2010. Albert the Great's Speculum Astronomiae and Four Centuries of Readers. Lewiston: The Edwin Mellen Press.

Hendrix, Scott E. 2011. Natural Philosophy or Science in Premodern Epistemic Regimes? The Case of the Astrology of Albert the Great and Galileo Galilei. Teorie vědy/Theory of Science: The Journal for Interdisciplinary Studies of Science 33: 111-32. 
Korsgaard, Christine M. 2008. Aristotle's Function Argument. In The Constitution of Agency: Essays on Practical Reason and Moral Psychology. Oxford: Oxford University Press, pp. 129-50.

Kuhn, Thomas. 1970. The Structure of Scientific Revolutions, 2nd ed. Chicago: The University of Chicago Press.

Latour, Bruno. 1988. The Pasteurization of France. Translated by Alan Sheridan, and John Law. Cambridge: Harvard University Press, p. 6.

Lemay, Richard. 1962. Abu Ma'shar and Latin Aristotelianism in the Twelfth Century. Beirut: American University of Beirut.

Longino, Helen. 1990. Science as Social Knowledge. Princeton: Princeton University Press, p. 12.

Lukes, Steven. 1967. Some Problems about Rationality. Archives of European Sociology 8: 247-64, 263. [CrossRef]

North, John D. 1986. Celestial influence-the major premise of astrology. In "Astrologi hallucinati": Stars and the End of the World in Luther's Time. Edited by Paola Zambelli. New York: Walter de Gruyter, pp. 45-100, 52-61. Pingree, David. 1968. The Thousands of Abu Ma' shar. Leiden: Brill, pp. 14-18.

Pingree, David. 1990. Astrology. In Religion, Learning, and Science in the 'Abbasid Period'. Edited by M. J. L. Young, J.

D. Latham and Robert Bertram Serjeant. Cambridge: Cambridge University Press, pp. 290-99.

Popper, Karl. 1975. Objective Knowledge: An Evolutionary Approach. Oxford: Oxford University Press, p. 176.

Sachs, Abraham. 1952. Babylonian Horoscopes. Journal of Cuneiform Studies 6: 49-74, 54-56. [CrossRef]

Sagan, Carl. 1980. The Harmony of the Worlds. In Cosmos. London: Fremantle Media Enterprise. PBS.

Swinburne, Richard. 2005. Faith and Reason, 2nd ed. Oxford: Oxford University Press, p. 17.

Tester, S. J. 1987. A History of Western Astrology. Woodbridge: Boydell Press.

Thorndike, Lynn. 1923. History of Magic and Experimental Science. New York: Columbia University Press, vol. II, pp. 584, 589.

Torrell, Jean-Pierre O.P. 2005. St. Thomas Aquinas: The Person and His Work. 2nd Printing. Translated by Robert Royal. Washington, DC: The Catholic University of America Press, p. 215.

Winch, Peter. 1964. Understanding a Primitive Society. American Philosophical Quarterly 1: 307-24.

Wippel, John F. 1977. The Condemnations of 1270 and 1277 at Paris. The Journal of Medieval and Renaissance Studies 7: 169-201.

Zambelli, Paola. 1982. Albert le Grand et l'astrologie. Recherches de Théologie Ancienne et Medieval 49: 141-58.

Zambelli, Paola. 1992. The Speculum Astronomiae and Its Enigma: Astrology, Theology, and Science in Albertus Magnus and His Contemporaries. Dordrecht: Kluwer Academic Publishers, chp. 3. p. 220.

(C) 2020 by the author. Licensee MDPI, Basel, Switzerland. This article is an open access article distributed under the terms and conditions of the Creative Commons Attribution (CC BY) license (http://creativecommons.org/licenses/by/4.0/). 